\title{
STOCKHOLM NATURAL RADIOCARBON MEASUREMENTS V
}

\author{
H. GÖTE ÖSTLUND and LARS G. ENGSTRAND \\ Radioactive Dating Laboratory, Frescati, Stockholm 50, Sweden \\ INTRODUCTION
}

This date list includes samples and sample series finished between January and November 1962. It does not include samples from series not yet been completed, or samples of very limited scientific interest.

Since the technical description of our dating system was published (Östlund, 1957a) a continuous development has been carried out both for improvement of the outfit, and considerable expansion of the facilities. In our date lists (Stockholm I, II, III, IV) we have mentioned only briefly some of the improvements. For the immediate future we do not anticipate any major technical changes, and therefore take the opportunity of giving a summary of our carbon-dioxide proportional-counting system as of fall 1962.

\section{Technical Description}

The chemical system for the preparation of extremely pure $\mathrm{CO}_{2}$ is almost unchanged compared with the description mentioned above, utilizing the "wet purification" method. For the last four years more than 800 samples have been run through this system, and an impure gas has been obtained only in a few cases where the impurities could be directly attributed to a leak in a vacuum system or exhausted fillings in the chromate or silver-copper ovens.

Compared with the 1957 description (Östlund, 1957a), the most extensive changes have been made regarding the $\mathrm{CO}_{2}$ proportional counters, four of which we have now in continuous use for routine dating. For a long intermediate time we had a construction with teflon ends, which has been described in connection with the natural tritium work of this laboratory (Östlund, 1962). In our efforts to obtain a type of counter, technically as simple as possible, containing as few materials as possible and being free from out gassing, we finally arrived at the construction given in Fig. 1. This construction is now used for the three one-liter $\mathrm{CO}_{2}$ counters in Stockholm, one in Miami (cf. Miami I) and two hydrogen Geiger counters for tritium. The copper counters are shielded with $25 \mathrm{~mm}$ of selected lead* inside a ring of $1 \mathrm{~m}$ cosmic ray Geiger counters and 10 to $20 \mathrm{~cm}$ of iron. The Geiger counters are quenched externally, which greatly increases their lifetime, now two to three years between refillings. All regular one-liter counters have background figures between 1.60 and 2.20 , and a net modern carbon count rate of 18.5 counts $/ \mathrm{min}$ at the normal operating pressure of $3 \mathrm{~atm}$ ( 1.3 plus 9.5 counts $/ \mathrm{min}$ for the $0.5 \mathrm{~L}$ counter). Working voltage is $7 \mathrm{kv}$, with a plateau length of more than $700 \mathrm{v}$ and a plateau slope of less than $1 \%$ per $100 \mathrm{v}$ for $\mathrm{C}^{14}$. For a counter shielded by lead, smaller cos. mic variation of net background is found than for the same counter shielded by mercury in an iron tank: $\partial \mathrm{n}_{\mathrm{o}} / \partial \mathrm{n} \mu<0.01$ inside lead, versus 0.02 inside mercury.

* This lead is commercially available from Bolidens Gruvaktiebolag, Sturegatan 22, Stockholm C, Sweden, under the name "Laisvall A" lead. 


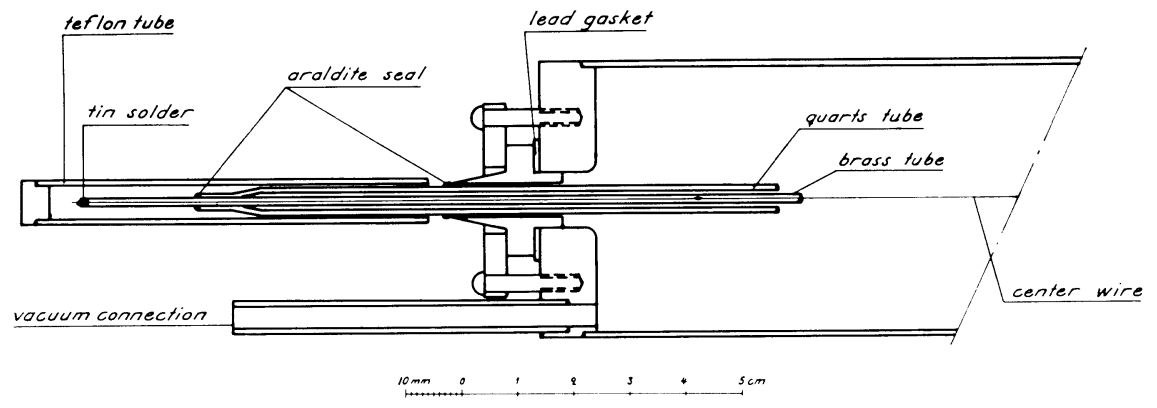

Fig. 1. Constructional detail of 3 atm one-liter $\mathrm{CO}_{2}$ proportional counter. Effective length of center wire $490 \mathrm{~mm}$, equivalent to $1.00 \mathrm{I}$ cylindric volume. Center wire $0.05 \mathrm{~mm}$ stainless steel. Material is copper tubing (electrolytic, commercial), and brass.

Standards and mode of calculation follow the recommendations given in the introduction to RADIOCARBON, v. 4 . Even if it is not stated in the sample descriptions, most dates younger than $5000 \mathrm{yr}$ have been corrected for isotopic fractionation by means of $\mathrm{C}^{13}$ measurements on the counting gas. $\delta \mathrm{C}^{13}$ was measured to $\pm 1 \%$. In each date without $\mathrm{C}^{13}$ measurements, \pm 40 yr squared have been incorporated in the $\sigma^{2}$ of the age figure.

The extension of the facilities to four routine counters was completed during the summer of 1962, and the laboratory is now capable of dating 400 unknown samples a year, with two days counting time for each sample. All the technical routine work and part of the calculations are now handled by two women technicians. Final calculations, supervision of the work, trouble shooting, and special projects take most of the time of one of the authors.

\section{ACKNOWLEDGMENTS}

The expansion and improvements of the facilities were made possible by generous grants from the King Gustav VI Adolf Foundation for Swedish Culture and the Swedish Wenner-Gren Foundation.

We are indebted to Mrs. Ingrid Almstedt for having excellently performed most of the routine work. As usual, Dr. R. Ryhage and his staff at the massspectrometric laboratory of the Karolinska Institutet have been of very great help by making the $\mathrm{C}^{13}$ determinations.

\section{SAMPLE DESCRIPTIONS}

\section{GEOLOGIC SAMPLES}

\section{St-806. Långören}

\section{A. Postglacial Strandlines}

Wood from pine stumps found in sand ca. $3 \mathrm{~m}$ below present sealevel in the strait between the islands Lilla Långören and Stora Långören $\left(56^{\circ} 03^{\prime} \mathrm{N}\right.$ Lat, $15^{\circ} 49^{\prime} \mathrm{E}$ Long), in the Baltic Sea, S of Torhamn, Blekinge, Sweden. Coll. by A. Andersson; subm. by B. E. Berglund, Dept. of Quat. Geol., Univ. of Lund. Comment (B.E.B.) : sample dates the transgression during the transition 
Yoldia/Ancylus time (Preboreal/Boreal time). The date may be compared with three other samples from this area of the Baltic, St-333 pine wood $4.0 \mathrm{~m}$ below present sealevel $9000 \pm 140$ в.P. (Stockholm I), St-120 pine stumps $43 \mathrm{~m}$ below sealevel $9100 \pm 120$ B.P. and St-179 pine stumps 35 to $37 \mathrm{~m}$ below sealevel $9330 \pm 120$ B.P. (Stockholm II).

\section{Sandbäcksviken series}

Peat situated at shore line of postglacial transgression limit at Sandbäcksviken $\left(56^{\circ} 06^{\prime} \mathrm{N}\right.$ Lat, $15^{\circ} 39^{\prime} \mathrm{E}$ Long), on Sturkö island, Blekinge, Sweden. Coll. and subm. by B. E. Berglund. Pollen-analytical dating is problematical.

\section{St-810. Sandbäcksviken I}

A.D. 1505

$445 \pm 80$

Sample from uppermost part of a peat layer, $20 \mathrm{~cm}$ thick, below $30 \mathrm{~cm}$ of eolian sand. The peat is underlain by littoral sand of the old beach.

\section{St-811. Sandbäcksviken II}

A.D. 1135

$815 \pm 70$

Sample from the lowest part of the same peat layer. Comment (B.E.B.) : these two samples date the eolian activity on the island.

\section{St-1003. Sandbäcksviken III}

$$
\begin{gathered}
2010 \pm 90 \\
60 \text { в.C. }
\end{gathered}
$$

Sample from peat layer below the above-mentioned littoral sand, supposed to date the Littorina beach. Comment (B.E.B.) : of some unknown reason the date is too young.

\section{Stockholm crustal uplift series}

Samples of mud from the isolation level of peat bogs and fens in the Stockholm region, investigated in order to study the process of crustal uplift in this area. Subm. by H. Möller, Geol. Survey of Sweden.

\section{St-808. Danderyd 2}

$$
1940 \pm 100
$$

$$
\text { A.D. } 10
$$

Vaucheria-mud from drained fen $\left(59^{\circ} 25^{\prime} \mathrm{N}\right.$ Lat, $18^{\circ} 03^{\prime} \mathrm{E}$ Long $), 350$ $\mathrm{m}$ ESE of Danderyd Church, $\mathrm{N}$ of Stockholm. Isolation level: $5 \mathrm{~m}$ above sealevel. Coll. by H. Möller.

\section{St-807. Brännkyrka 6}

$4235 \pm 110$ 2285 в.c.

Vaucheria-mud collected in a drained fen $\left(59^{\prime} 17^{\circ} \mathrm{N} \mathrm{Lat,} 18^{\circ} 00^{\prime} \mathrm{E}\right.$ Long), $1850 \mathrm{~m} \mathrm{~W}$ of Brännkyrka Church, $6 \mathrm{~km} \mathrm{SW}$ of central Stockholm. Isolation level: $22 \mathrm{~m}$ above sealevel. Coll. by H. Möller.

\section{St-809. Sandasjömossen 8}

$$
5020 \pm 80
$$$$
3070 \text { в.C. }
$$

Mud collected in a profile of the bog Sandasjömossen $\left(59^{\circ} 16^{\prime} \mathrm{N}\right.$ Lat, $18^{\circ} 11^{\prime}$ E Long), $500 \mathrm{~m} \mathrm{~W}$ of the Lake Sandasjön, $8 \mathrm{~km} \mathrm{SE}$ of central Stockholm. Sample is taken 325 to $330 \mathrm{~cm}$ below surface in the center of the bog. Isolation level: $36 \mathrm{~m}$ above sealevel. Coll. by C. Larsson, Geol. Survey of Sweden. 


\section{St-789. Snöromsmossen 8}

Mud collected in a profile of the bog Snöromsmossen $\left(59^{\circ} 17^{\prime} \mathrm{N}\right.$ Lat, $18^{\circ} 12^{\prime} \mathrm{E}$ Long), $1 \mathrm{~km} \mathrm{E}$ of S shore of the Lake Källtorpssjön, $7 \mathrm{~km}$ ESE of central Stockholm. Sample was taken 335 to $340 \mathrm{~cm}$ below surface (core 15). Isolation level: $41 \mathrm{~m}$ above sealevel. Coll. by C. Larsson.

\section{St-788. Källtorpsmossen 4}

$6170 \pm 110$

Mud collected in a profile of the bog Källtorpsmossen $\left(59^{\circ} 16^{\prime} \mathrm{N}\right.$ Lat, $18^{\circ} 11^{\prime} \mathrm{E}$ Long), $1 \mathrm{~km} \mathrm{E}$ of $\mathrm{N}$ shore of Källtorpssjön, $7 \mathrm{~km}$ ESE of central Stockholm. Sample was taken 420 to $425 \mathrm{~cm}$ below surface (core 5). Isolation level: ca. $55 \mathrm{~m}$ above sealevel. Coll. by C. Larsson.

\section{St-970. Apelvreten 33}

$$
\begin{aligned}
& \mathbf{5 1 6 0} \pm 100 \\
& \mathbf{3 2 1 0} \text { в.с. }
\end{aligned}
$$

Mud collected in a profile of a bog $700 \mathrm{~m} \mathrm{E}$ of Apelvreten $\left(59^{\circ} 17^{\prime} \mathrm{N}\right.$ Lat, $18^{\circ} 25^{\prime} \mathrm{E}$ Long), $1700 \mathrm{~m} \mathrm{~W}$ of Ingarö Church, $18 \mathrm{~km}$ ESE of central Stockholm, 360 to $370 \mathrm{~cm}$ below surface (core 3). Isolation level: $34.5 \mathrm{~m}$ above sealevel. Coll. by C. Larsson.

\section{St-968. Blåbärsmossen 36}

$4800 \pm 110$

2850 в.C.

Mud collected in a profile of the bog Stora Blåbärsmossen $\left(59^{\circ} 24^{\prime} \mathrm{N}\right.$ Lat, $18^{\circ} 13^{\prime}$ E Long), $6 \mathrm{~km}$ SSE of östra Ryd Church, $11 \mathrm{~km} \mathrm{NE}$ of central Stockholm, 185 to $200 \mathrm{~cm}$ below surface (core 3). Isolation level: $32 \mathrm{~m}$ above sealevel. Coll. by C. Larsson.

\section{St-969. Fågelsången 3}

$3750 \pm 100$

1800 в.C.

Mud collected in a profile of bog $\mathrm{E}$ of Fågelsången $\left(59^{\circ} 30^{\prime} \mathrm{N}\right.$ Lat, $18^{\circ}$ 06' E Long), $3 \mathrm{~km}$ ENE of Täby Church, $9 \mathrm{~km} \mathrm{~N}$ of central Stockholm, 305 to $320 \mathrm{~cm}$ below surface (core 3). Isolation level: ca. $22.5 \mathrm{~m}$ above sealevel. Coll. by C. Larsson.

\section{Alsmyren series}

Two samples of peat from the bog Alsmyren $\left(61^{\circ} 52^{\prime} \mathrm{N}\right.$ Lat, $16^{\circ} 12^{\prime} \mathrm{E}$ Long), ENE of Ljusdal, Hälsingland, Sweden. Samples were collected from clay at the isolation level, which is now $200 \mathrm{~m}$ above present day sealevel. Coll. 1961 and subm. by G. Lundqvist, Geol. Survey of Sweden.

\section{St-879. Alsmyren 10}

420 to $425 \mathrm{~cm}$ below surface.

\section{St-875. Alsmyren 9}

$430 \mathrm{~cm}$ below surface.

\section{B. Recurrence Surfaces}

$6990 \pm 80$ $\mathbf{5 0 4 0}$ в.c.

$7360 \pm 100$ 5410 в.C.

\section{Snöromsmossen series}

Peat collected in a profile of the bog Snöromsmossen $\left(59^{\circ} 17^{\prime} \mathrm{N}\right.$ Lat, $18^{\circ}$ 
$12^{\prime} \mathrm{E}$ Long), $1 \mathrm{~km} \mathrm{E}$ of the southern shore of the Lake Källtorpssjön, $7 \mathrm{~km}$ ESE of central Stockholm, Sweden. These samples were investigated in order to study the development of the bog, especially its recurrence surfaces. Coll. 1960 by C. Larsson; subm. by H. Möller.

\section{St-966. Snöromsmossen 6}

$1230 \pm 90$

80 to $90 \mathrm{~cm}$ below surface in core 7 .

\section{St-967. Snöromsmossen 7}

170 to $175 \mathrm{~cm}$ below surface in core 7 .

$$
\begin{aligned}
& 2640 \pm 100 \\
& 690 \text { в.с. }
\end{aligned}
$$

\section{Tisjön series}

Peat samples from a raised bog, $\mathrm{S}$ of the lake Tisjön $\left(60^{\circ} 52^{\prime} \mathrm{N}\right.$ Lat, $13^{\circ}$ $03^{\prime}$ E Long), NW Dalarna, Sweden. Investigated for its palynologic interest (Lundqvist, 1951), especially the development of recurrence surfaces. Coll. 1960 by C. Larsson; subm. by Uddeholm Ltd., through G. Lundqvist. Depth in $\mathrm{cm}$ below surface is given, each sample being $5 \mathrm{~cm}$ thick. Figures inside

\begin{tabular}{|c|c|c|c|}
\hline St-761. & Tisjön 1 & $35(35) \mathrm{cm}$ & $\begin{aligned} 720 & \pm 70 \\
\text { A.D. } 1230 & \end{aligned}$ \\
\hline St-762. & Tisjön 2 & $70(70) \mathrm{cm}$ & $\begin{array}{r}1270 \\
\text { A.D. } 680\end{array}$ \\
\hline St-763. & Tisjön 3 & $110(110) \mathrm{cm}$ & $\begin{aligned} 1700 & \pm 110 \\
\text { A.D. } 250 & \end{aligned}$ \\
\hline St-764. & Tisjön 4 & $130(135) \mathrm{cm}$ & $\begin{array}{l}3040 \pm 95 \\
1090 \text { в.с. }\end{array}$ \\
\hline St-766. & Tisjön 5 & $200(205) \mathrm{cm}$ & $\begin{array}{l}5150 \pm 150 \\
3200 \text { в.с. }\end{array}$ \\
\hline St-768. & Tisjön 6 & $260(260) \mathrm{cm}$ & $\begin{array}{l}6030 \pm 190 \\
4080 \text { в.с. }\end{array}$ \\
\hline St-767. & Tisjön 7 & $285(310) \mathrm{cm}$ & $\begin{array}{l}7630 \pm 230 \\
5680 \text { в.с. }\end{array}$ \\
\hline
\end{tabular}
brackets refer to depth indications in the pollen-diagram of the cited paper.

\section{Långsjömyren series}

Samples of peat from the bog Långsjömyren $\left(61^{\circ} 31^{\prime} \mathrm{N}\right.$ Lat, $15^{\circ} 28^{\prime} \mathrm{E}$ Long), near Voxna, Gästrikland, Sweden. Taken in order to date a recurrence surface. Coll. 1957 by C. Larsson; subm. by G. Lundqvist.

\section{St-876. Långsjömyren 13 \\ $1050 \pm 70$}

Sphagnum peat $90 \mathrm{~cm}$ below surface, just above the recurrence surface.

\section{St-877. Långsjömyren 14}

$$
\begin{array}{r}
1700 \\
\text { A.D. } 250
\end{array}
$$

Sphagnum peat $100 \mathrm{~cm}$ below surface, just underneath the recurrence 
surface. Comment (G.L.) : the surface apparently began to form 1700 B.P. but the peat growth did not commence again until 1050 B.P., which is a surprisingly large time difference.

\section{Various Geologic Problems}

\section{Ageröd series}

Peat and gyttja samples from the raised bog Ageröds mosse $\left(55^{\circ} 56^{\prime} \mathrm{N}\right.$ Lat, $13^{\circ} 26^{\prime}$ E Long), $3 \mathrm{~km} \mathrm{NW}$ of the lake Ringsjön. Skåne, Sweden. Dated as part of an extensive pollen-analytical investigation of bog development, recurrence surfaces, vegetational history, and human settlement in the surroundings. Most samples were cut out from a core $(\operatorname{diam} 6 \mathrm{~cm})$ taken by a piston sampler (type Borro) in the central part of the bog (profile P 100). The samples from the uppermost $100 \mathrm{~cm}$ were taken in a dug wall. Coll. and subm. by Tage Nilsson, Dept. of Quat. Geol., Univ. of Lund, Sweden. Depth given is that below surface of the bog.

\section{St-976. Ageröd 14}

Fresh Sphagnum peat, 34 to $38 \mathrm{~cm}$.

\section{St-977. Ageröd 26}

Fresh Sphagnum peat, 85 to $90 \mathrm{~cm}$.

St-978. Ageröd 27

Fresh Sphagnum peat, 94 to $98 \mathrm{~cm}$.

\section{St-979. Ageröd 32}

Fresh Sphugnum peat, 118 to $121 \mathrm{~cm}$.

\section{St-982. Ageröd 33}

Highly humified Sphagnum peat, 122 to $127 \mathrm{~cm}$.

\section{St-983. Ageröd 43}

Highly humified Sphagnum peat, 169 to $175 \mathrm{~cm}$.

\section{St-985. Ageröd 44}

Humified Sphagnum peat, 175 to $181 \mathrm{~cm}$.

St-986. Ageröd 45

$$
430 \pm 80
$$
A.D. 1520

$$
\begin{aligned}
& 1090 \pm 85 \\
& \text { A.D. } 860 \\
& 1250 \pm 85 \\
& \text { A.D. } 700 \\
& 1495 \pm 85
\end{aligned}
$$

A.D. 455

$1645 \pm 95$

A.D. 305

$$
\begin{gathered}
1935 \pm 80 \\
\text { A.D. } 15 \\
2140 \pm 85 \\
190 \text { в.C. } \\
2205 \pm 85 \\
\mathbf{2 5 5} \text { в.C. }
\end{gathered}
$$

Highly humified Sphagnum peat with much Eriophorum vaginatum, 181 to $186 \mathrm{~cm}$.

\section{St-987. Ageröd 46}

$2845 \pm 90$

Highly humified Sphagnum peat, 190 to $194 \mathrm{~cm}$.

\section{St-988. Ageröd 51}

$3205 \pm 85$

Highly humified Sphagnum peat, 211 to $216 \mathrm{~cm}$.

\section{5 в.C.}


St-989. Ageröd 52

$3315 \pm 90$

1365 в.C. to $224 \mathrm{~cm}$.

Highly humified Sphagnum peat with much Eriophorum vaginatum, 218

\section{St-1050. Ageröd 55}

Highly humified Sphagnum peat, $232-235 \mathrm{~cm}$.

\section{St-990. Ageröd 60}

Highly humified Sphagnum peat, 256 to $260 \mathrm{~cm}$.

St-996. Ageröd 69

Humified Sphagnum peat, 296 to $299 \mathrm{~cm}$.

\section{St-997. Ageröd 76}

Highly humified Sphagnum peat, 325 to $329 \mathrm{~cm}$.

\section{St-998. Ageröd 77}

Highly humified Sphagnum peat, 329 to $333 \mathrm{~cm}$.

St-792. Ageröd 87

Carex-Sphagnum peat, 371 to $375 \mathrm{~cm}$.

St-790. Ageröd 88

Carex-Sphagnum peat, 375 to $379 \mathrm{~cm}$.

St-1000. Ageröd 95

Magnocaricetum peat, 404 to $409 \mathrm{~cm}$.

St-791. Ageröd 100

Magnocaricetum peat, 427 to $431 \mathrm{~cm}$.

\section{St-794. Ageröd 111}

Muddy Phragmites peat, 477 to $481 \mathrm{~cm}$.

\section{St-1001. Ageröd 120}

Gyttja, 507 to $509 \mathrm{~cm}$.

\section{St-1002. Ageröd 132}

Algae-gyttja, 536.5 to $539 \mathrm{~cm}$.

St-1004. Ageröd 134

Algae-gyttja, 540 to $542 \mathrm{~cm}$.

\section{St-795. Ageröd 135}

Algae-gyttja, 542 to $544 \mathrm{~cm}$. 
St-796. Ageröd 137

$9180 \pm 110$

7230 в.с.

Algae-gyttja, 546.5 to $549 \mathrm{~cm}$.

St-797. Ageröd 139

$8980 \pm 120$

7030 в.с.

Algae-gyttja, 551.5 to $554 \mathrm{~cm}$.

St-1018. Ageröd 143

$9590 \pm 120$

Algae-gyttja, 561 to $563 \mathrm{~cm}$.

7640 в.с.

St-800. Ageröd 144

$9590 \pm 160$

7640 в.с.

Fine detritus gyttja transitional to lime-gyttja, Pre-boreal, 563 to $566 \mathrm{~cm}$.

St-801. Ageröd 145

$9880 \pm 160$

Fine detritus gyttja transitional to lime-gyttja, Pre-boreal, 566 to $569 \mathrm{~cm}$.

\section{St-805. Ageröd 146}

$9920 \pm 150$

7970 в.C.

Fine detritus gyttja transitional to lime-gyttja, Pre-boreal, 569 to $572 \mathrm{~cm}$.

St-799. Ageröd 147

Clay-gyttja, Late-glacial, 572 to $574 \mathrm{~cm}$.

\section{St-798. Ageröd 148}

$10,430 \pm 180$ 8480 в.с.

$10,680 \pm 280$

8730 в.C.

Clay-gyttja with layers of fine sand, Late-glacial, 574.5 to $578 \mathrm{~cm}$.

\section{St-874. Långströmmen}

$3760 \pm 70$

1810 в.с.

Wood from stump in situ of a tree having grown on what is now the bottom of the river Ljusnan at Långströmmen $\left(62^{\circ} 05^{\prime} \mathrm{N} \mathrm{Lat}, 14^{\circ} 58^{\prime} \mathrm{E}\right.$ Long), Jämtland, Sweden. The stump was revealed by the construction work for a dam. Coll. 1960 and subm. by G. Lundqvist.

\section{St-780. Gallejaure}

Sample of muddy silt from borings at Gallejaure $\left(65^{\circ} 09^{\prime} \mathrm{N} \mathrm{Lat}, 19^{\circ} 28^{\prime}\right.$ E Long), Västerbotten, Sweden. The silt was situated within varved finegrained sediments, under ca. $17 \mathrm{~m}$ of moraine and other drift. The age of the organic matter is thus assumed to be interglacial or interstadial. The deposit contained no macroscopic remains. Coll. 1960; subm. and described 1962 by Ernest Magnusson, Geol. Survey of Sweden.

\section{North Seandinavian Local Glaciation series}

A series of peat samples collected in order to determine the variation in size of the pre-recent local glaciation in the Scandinavian mountains. This is partly a continuation of the Norwegian local glaciation series in Uppsala II. Subm. by Erik Bergström, Dept. of Geog., Univ. of Stockholm. 
St-928. Skanatjåkko

$1305 \pm 80$

A.D. 645

Peat from the bottom of a bog situated inside a terminal moraine at Skanatjåkko ( $67^{\circ} 27^{\prime} \mathrm{N}$ Lat, $18^{\circ} 02^{\prime} \mathrm{E}$ Long), Lappland, Sweden. Coll. 1960 by Lennart Vilborg. Estimated age: $<6000 \mathrm{yr}$.

St-936. Nakerivaara

$4920 \pm 80$

2970 в.c.

Peat from the bottom of a lake inside a terminal moraine at Nakerivaara ( $68^{\circ} 11^{\prime} \mathrm{N}$ Lat, $19^{\circ} 45^{\prime} \mathrm{E}$ Long), Lappland, Sweden. Coll. 1962 by Erik Bergström. Estimated age: ca. 8000 yr.

\section{St-927. Heimerdalsvand}

$3850 \pm 80$

1900 в.с.

Peat between boulders accumulated during the last Tapestransgression ca. $85 \mathrm{~cm}$ below surface at Heimerdalsvand $\left(68^{\circ} 18^{\prime} \mathrm{N}\right.$ Lat, $13^{\circ} 38^{\prime} \mathrm{E}$ Long $)$, Lofoten, Norway. Coll. 1958 by Erik Bergström. Estimated age: between 3440 and 5860 yr B.P. Samples from this location have been dated in Uppsala (U-97, U-98 and U-99, Uppsala II).

\section{Rangárbotnar series}

Samples of charred wood from two important tephra (ash) horizons at Rangárbotnar $\left(64^{\circ} 04^{\prime} \mathrm{N}\right.$ Lat, $19^{\circ} 45^{\prime} \mathrm{W}$ Long), $10 \mathrm{~km}$ NE of the volcano Hekla, Iceland. Coll. and subm. by Sigurdur Thorarinsson, Dept. of Geol. and Geog., Mus. of Natl. History, Reykjavík.

\section{St-813. Rangárbotnar, Cd 49}

$$
\begin{aligned}
& 2820 \pm 70 \\
& 870 \text { в.с. }
\end{aligned}
$$

A birch having been charred and covered by hot rhyolitic pumice from an explosive Hekla eruption. This layer has been called $\mathrm{H}_{3}$ (Thorarinsson, 1951) and is the heaviest and most extensive postglacial tephra layer in Iceland, covering $80,000 \mathrm{~km}^{2}$ on land (Thorarinsson, 1960). Its age was estimated to "not less than 2500-probably nearer 3000 yr" (Thorarinsson, 1951, p. 11). Peat immediately below this layer has been dated by the Yale laboratory (Y85, Yale II) at $2720 \pm 130$ (Thorarinsson, 1954).

\section{St-814. Rangárbotnar, Cd 50}

$2660 \pm 80$ 710 в.c.

Charred remnants of another birch buried in a brown pumice layer a few hundred meters $\mathrm{E}$ of sample $\mathrm{Cd} 49$. This layer, which is separated from layer $\mathrm{H}_{3}$ by a layer of eolian soil and tephra, $30 \mathrm{~cm}$ thick, is also important, existing over large areas of S Iceland. Its age was roughly estimated to be ca. $2000 \mathrm{yr}$.

\section{ARCHAEOLOGIC SAMPLES-SWEDEN}

\section{A. History of Iron Manufacturing}

\section{Grunuberg series}

Charcoal imbedded in slag from two ancient iron manufacturing furnaces, so-called Osmund forges, at Orsa $\left(61^{\circ} 06^{\prime} \mathrm{N}\right.$ Lat, $14^{\circ} 51^{\prime} \mathrm{E}$ Long), Dalarna. Coll. 1961 by E. Berg; subm. by Jan Lundqvist. 
St-880. Grunuberg 1

St-881. Grunuberg 2
$825 \pm 80$

A.D. 1125

$290 \pm 75$

A.D. 1660

$380 \pm 75$

\section{St-956. Östnår}

A.D. 1570

Charcoal imbedded in iron furnace slag from a slag-mound, at östnår $\left(62^{\circ} 55^{\prime} \mathrm{N}\right.$ Lat, $14^{\circ} 33^{\prime} \mathrm{E}$ Long), Jämtland. The fact that no tradition of iron manufacturing from bog-ore can be traced to this place indicates the sample is at least one or two hundred years old. Coll. 1962 by Maj Nodermann; subm. by Margareta Biörnstad, Royal Office of Natl. Antiquities, Stockholm.

\section{St-787. Kvillehed boat}

\section{B. History of Ship-Building}

$$
2135 \pm 105
$$

185 в.с.

Wood from a boat made of a tree trunk found at Kvillehed $\left(57^{\circ} 48^{\prime} \mathrm{N}\right.$ Lat, $11^{\circ} 51^{\prime} \mathrm{E}$ Long), $11 \mathrm{~km} \mathrm{NW}$ of Göteborg, Bohuslän. The boat, which has been investigated carefully, was excavated 1953 by $\AA$. Fredsjö. It was preserved by surface treatment with linseed oil, but the samples for $\mathrm{C}^{14}$ were taken from an uncontaminated part of the material by G. Lindman and $\mathrm{O}$. Lindqvist. The boat has been dated to ca. A.D. 300, according to pollen and diatom analysis. Subm. by C. A. Moberg, Archaeol. Mus., Göteborg. Comment (C.A.M. and G.ö.) : the discrepancy between estimated age and $\mathrm{C}^{14}$ date may be due to the apparently high age of the tree from which the boat was made. Sample taken from "early" year rings.

\section{St-784. Söderbysjön}

$$
\begin{array}{r}
\mathbf{9 7 0} \pm \mathbf{8 0} \\
\text { A.D. } 980
\end{array}
$$

Wood from a boat, found standing vertically with one end in the bottom mud at a water depth of ca. $2 \mathrm{~m}$ in the lake Söderbysjön $\left(59^{\circ} 17^{\prime} \mathrm{N}\right.$ Lat, $18^{\circ}$ 09' E Long), Nacka, SW of Stockholm. Coll. 1961 and subm. by H. Ahnlund, City Mus. of Stockholm.

\section{St-916. Enköping boat}

\section{A.D. 1060}

$$
890 \pm 65
$$

Wood from a plank belonging to a ship discovered $176 \mathrm{~cm}$ below the surface of the street Munksundsgatan, at the ruins of the monastery church of Enköping ( $59^{\circ} 38^{\prime} \mathrm{N}$ Lat, $17^{\circ} 05^{\prime} \mathrm{E}$ Long), Uppland. The planks were lying upon a stratum of blue clay with separate splinters of brick and were covered with a layer of burnt occupation soil, 3 to $5 \mathrm{~cm}$ thick. This ship was clinkerbuilt and is supposed to belong to the Medieval period. (Oral communication by Dr. O. Hasslöf, Natl. Maritime Mus. of Stockholm.) Coll. 1960 by O. Ehn, Upplands Mus.; subm. by S. Sjöberg, The Enköping Mus., Enköping.

\section{St-786. Penningby boat}

$$
\begin{array}{r}
1060 \\
\text { A.D. } 890
\end{array}
$$

Wood from a boat made from an oak trunk, found at the end of the nine- 
teenth century by cutting peat in a bog near the lake Bergasjön $\left(59^{\circ} 41^{\prime} \mathrm{N}\right.$ Lat, $18^{\circ} 42^{\prime} \mathrm{E}$ Long), Penningby, $9 \mathrm{~km} \mathrm{~S}$ of Norrtälje, Uppland. The boat is $600 \mathrm{~cm}$ long and has a beam of $59 \mathrm{~cm}$. It is now preserved and kept at Penningby Castle. Subm. by R. Holmerin.

\section{Various Archaeologic Samples, Sweden, except Lappland}

\section{Skedemosse series}

Wood samples from the drained fen Skedemosse $\left(56^{\circ} 50^{\prime} \mathrm{N}\right.$ Lat, $16^{\circ} 45^{\prime}$ E Long), Öland. Another part of this series has been dated previously (Stockholm II) and the site was briefly described there. The site, which is archaeologically very rich, has been described by Ulf Hagberg, Royal Office of Natl. Antiquities (Hagberg, 1961, 1962), and the samples were subm. by him. Coll. 1960 and 1961 by Ulf Hagberg and L.-K. Königsson. Pollen analysis has been made by L.-K. Königsson on most of the samples.

\section{St-828. Skedemosse R 19 G $\quad 4570$ ¿ 75}

Wooden stick in layer of Carex peat within the distal sandy part of the so-called Ancylus ridge, $27 \mathrm{~cm}$ below the surface.

\section{St-829. Skedemosse 9 G}

$2460 \pm 80$

Wooden stick in gyttja, 30 to $35 \mathrm{~cm}$ below the surface.

\section{St-830. Skedemosse 259}

Burned piece of pine-wood, imbedded in the sand layer representing the first stage of the lake. This stick might have served as a torch for the earliest fishermen. The sample should be connected with St-518 (9200 \pm 160 , Stockholm IV) when discussing the formation of the lake.

\section{St-832. Skedemosse 260:XI}

Wooden pole, probably the remains of some sort of fishing-tackle.

\section{St-833. Skedemosse 260:VII}

$2890 \pm 75$

Another pole in the same system of poles as $\mathrm{St}-832$.

\section{St-834. Skedemosse Ad 3 G}

$$
9080 \pm 140
$$

7130 в.c.

Piece of wood within a sandy bar in the eastern part of the basin, $60 \mathrm{~cm}$ below surface.

St-835. Skedemosse 5 G

Stick in a layer with molluscs (Bithynia tentaculata, Planorbis sp., Limnaea sp., Valvata sp.) and coarse detritus, $28.5 \mathrm{~cm}$ below surface.

\section{St-945. Västra Hagen}

$$
2750 \pm 150
$$

800 в.C.

Charcoal from a Mesolithic settlement at Västra Hagen $\left(57^{\circ} 27^{\prime} \mathrm{N}\right.$ Lat, $11^{\circ} 56^{\prime} \mathrm{E}$ Long), Halland. The material was collected above and between the 
stones of a hearth stratigraphically situated underneath a culture level. The top stones of the hearth reached up into the lowest part of this stratum. Artifacts of flint from this site are undoubtedly Mesolithic, but unfortunately artifacts directly connected with the hearth were lacking. According to Fredsjö (1953) the site has been used at two different periods, and the hearth in question should belong to the first occupation. Coll. 1952 by Åke Fredsjö, subm. by Carl-Axel Moberg, Gothenburg Archaeol. Mus. Comment (C.A.M.) : cf. comment on Tosskär series.

\section{Tosskärr series}

Charcoal from hearth in a presumed Mesolithic site at Tosskärr $\left(57^{\circ} 55^{\prime}\right.$ N Lat, $11^{\circ} 38^{\prime}$ E Long), Bohuslän. Coll. 1952 by Åke Fredsjö; subm. by CarlAxel Moberg.

\section{St-944. Tosskärr I}

Location A, D:-5.

\section{St-946. Tosskärr II}

Location A, C:-3. Bottom layer.

\section{St-947. Tosskärr III}

Location A, C:-3. Upper layer.

General comment: according to Fredsjö (1953) this hearth belongs to the settlement. The flint artifacts of the site are undoubtedly Mesolithic, but the possibility that the hearth is younger, cannot be entirely excluded. Additional samples from this site have been dated by $\mathrm{H}$. Tauber in the Copenhagen $\mathrm{C}^{14}$ dating lab. They also indicate similar inconsistencies. (Oral communication by J. Troels-Smith, Natl. Mus., Copenhagen.)

\section{St-929. Vittene}

$$
\mathbf{2 9 4 0} \pm \mathbf{8 0}
$$

990 в.C.

Materials from six resin cakes found by digging a ditch on the farm Högerna, at Vittene $\left(58^{\circ} 15^{\prime} \mathrm{N}\right.$ Lat, $12^{\circ} 31^{\prime} \mathrm{E}$ Long), N Björke, Västergötland. Coll. 1928; subm. by S. A. Hallbäck, Vänersborg Mus., Vänersborg. Resin cakes found very close to this find have been dated by us to $2945 \pm 75$ (St-690, Stockholm IV).

\section{Halleby series}

Charcoal from remains of a house and culture layers at Halleby $\left(58^{\circ} 42^{\prime}\right.$ $\mathrm{N}$ Lat, $19^{\circ} 57^{\prime} \mathrm{E}$ Long), Östergötland. These samples were dated as a part of a large investigation of the early settlements and their agriculture, and to establish possible earlier devastations of cultivated land. All samples are charcoal from house remains, or charcoal horizons resulting from the intentional clearing of land by fire. Coll. 1960 to 1962; subm. and partly described by Sven-Olof Lindquist (1961), Dept. of Geog., Univ. of Stockholm.

\section{St-622. Halleby 7}

$$
1930 \pm 100
$$

Posthole $70 \mathrm{~cm}$ below surface. House Ia.

\section{A.D. 20}




\section{St-633. Halleby 20}

Hearth $50 \mathrm{~cm}$ below surface. House Ia.

\section{St-625. Halleby 14}

Charcoal horizon $20 \mathrm{~cm}$ below surface. House Ib.

St-636. Halleby 27

Charcoal horizon $25 \mathrm{~cm}$ below surface.

\section{St-884. Halleby 77}

Burned remnants of house construction. House II.

\section{St-883. Halleby 35}

Hearth $45 \mathrm{~cm}$ below surface. House IIIa.

\section{St-882. Halleby 34.}

$$
1500 \pm 80
$$

A.D. 450

A.D. 1270

$$
680 \pm 70
$$

A.D. 1275

$$
675 \pm 85
$$

$$
1330 \pm 60
$$
A.D. 620

$$
1760 \pm 80
$$

A.D. 190

$$
\begin{array}{r}
1550 \pm 60 \\
\text { A.D. } 400
\end{array}
$$

Burned remnants of house construction $25 \mathrm{~cm}$ below surface. House IIIb.

\section{St-885. Halleby 101}

Posthole 30 to $40 \mathrm{~cm}$ below surface. House IIIb.

\section{St-1005. Halleby 30}

Charcoal horizon. $15 \mathrm{~cm}$ below surface.

\section{St-1006. Halleby 31}

$$
1760 \pm 70
$$

$$
\text { A.D. } 190
$$

$$
\text { A.D. } 1645
$$

$$
305 \pm 70
$$

$1935 \pm 120$

A.D. 15 file as Halleby 30.

\section{St-1007. Halleby 40}

Charcoal horizon $25 \mathrm{~cm}$ below surface.

$$
1815 \pm 90
$$
A.D. 135

\section{St-1008. Halleby 50}

Charcoal horizon $25 \mathrm{~cm}$ below surface.

\section{St-1009. Halleby 60}

Charcoal horizon $20 \mathrm{~cm}$ below surface.

\section{St-1010. Halleby 70}

Charcoal horizon $30 \mathrm{~cm}$ below surface.

\section{St-957. Odenslunda}

\section{Resin cake from Odenslunda $\left(59^{\circ} 31^{\circ} \mathrm{N}\right.$ (900 в.c.$$
490 \text { в.c. }
$$

$$
1935 \pm 90
$$

A.D. 15

A.D. 1530

$$
420 \pm 80
$$

$$
1905 \pm 100
$$$$
\text { A.D. } 45
$$

$$
2440 \pm 70
$$

( V. Ginters; holm. This resin. by B. Ambrosiani, Royal Office of Natl. Antiquities, Stock(Stockholm IV). 


\section{St-783. Flemmingsberg $3 / 28$}

Resin lump from Migration period gravefield at Flemmingsberg $\left(59^{\circ} 20^{\prime}\right.$ $\mathrm{N}$ Lat, $17^{\circ} 59^{\prime} \mathrm{E}$ Long), Huddinge. The resin should be connected with either of two earlier settlements, one from transition between the Mesolithic and the Neolithic Age, or possibly with the earliest phase of the Neolithic (dated by raised shore lines and by quartz), the other from the Iron Age (dated on pottery). Coll. and subm. by E. Baudou, Dept. of Nordic and Comparative Archaeol., Univ. of Stockholm. Comment (E.B.) : $\mathrm{C}^{14}$ date shows the sample to belong to the younger of the two settlements.

\section{Darsgärde series}

Charcoal from an ancient site at Dargärde $\left(59^{\circ} 43^{\prime} \mathrm{N}\right.$ Lat, $18^{\circ} 30^{\prime} \mathrm{E}$ Long), Uppland. The complex includes grave-fields and an ancient hill-fort with with at least two distinct occupation layers. The oldest layer exhibits contacts with Finnish and Estonian Bronze-Age culture. All fortifications seem to belong to the younger layer which contains artifacts from pure Swedish middle Iron Age only. The two layers probably represent the beginning and end of the settlement to which the gravefields belong. The complex is described by Ambrosiani $(1958,1959)$. Coll. 1957 to 1959; subm. by B. Ambrosiani. Part of this series has been dated earlier in Uppsala (U-18 and U-19, Uppsala I), and samples from the grave-fields will be dated later.

Charcoal from the W wall of the hill fort

St-886. Darsgärde 10

\section{St-887. Darsgärde 11}

St-888. Darsgärde 15

Charcoal from the $\mathrm{N}$ wall of the hill fort

St-889. Darsgärde 22

St-890. Darsgärde 25

St-891. Darsgärde 33

St-1017. Darsgärde 34

St-1019. Darsgärde 56

St-896. Darsgärde 57

$$
\begin{array}{r}
1560=70 \\
\text { A.D. } 390 \\
1470
\end{array}
$$

$1630 \pm 80$ A.D. 320

$$
\begin{array}{r}
1610 \pm 70 \\
\text { A.D. } 340 \\
1605 \pm 65
\end{array}
$$

A.D. 345

$1470 \pm 65$

A.D. 480

$1675 \pm 75$

A.D. 275

$1590 \pm 70$ A.D. 360

$1525 \pm 110$

A.D. 425

The last two samples from another profile than the four above. 
Charcoal from the top of the lowest culture layer inside the hill fort:

St-892. Darsgärde 38

\section{St-893. Darsgärde 39}

$1625 \pm 110$

A.D. 325

$1610 \pm 110$

Comment (B.A.): these two samples were found in a layer with artifacts belonging to the older stage ca. 500 B.c.), but the compressed stratigraphy of these turf charcoal layers may well be the cause of the younger age obtained.

Charcoal from buildings belonging to the later culture layer:

St-894. Darsgärde 53

St-895. Darsgärde 55

\section{St-785. Penningby palisade}

Wood remnants of a palisade around a small hill, formerly an island, the site of a small fortress defending the passage from the Baltic to the Lake Väsbysjön at Penningby (59 $41^{\prime} \mathrm{N}$ Lat, $18^{\circ} 42^{\prime}$ E Long), $9 \mathrm{~km} \mathrm{~S}$ of the city of Norrtälje, Uppland. This fortress was probably burnt down. In the late Middle Ages it was replaced by the present Penningby Castle, situated on the lake ca. $3 \mathrm{~km} \mathrm{~W}$ of the hill. Subm. by R. Holmerin through the State Mus. of Natl. History.

\section{Archaeology of Lappland}

\section{Malgomaj-Varris series}

Charcoal from four settlements and a system of trapping pits at the lakes Varris and Grundsjön (64. $42^{\prime} \mathrm{N}$ Lat, $16^{\circ} 24^{\prime} \mathrm{E}$ Long), S of Lake Malgomaj, $14 \mathrm{~km} \mathrm{NW}$ of Vilhelmina, Lappland. The sites consist mostly of low moraine ridges, now covered with pine forests and surrounded by water and moor. They show no defined stratigraphy. Site 673 is quite empty of finds. Sites 654, 657 and 662 contain rich and varying material: stone artifacts, metals (bronze, iron, lead), molds of soapstone, asbestos ceramics. The finds seem to indicate a long period of settlement from the Late Neolithic period right into historical time. In some hearths, metal, ceramics and stone artifacts were found, in others only stone artifacts. Not all the finds are necessarily contemporary with the hearths. The $\mathrm{C}^{14}$ dating of this series is intended to reveal the time intervals during which the different hearths, cooking- and trapping pits have been in use. Thereby archaeological dating of the finds is greatly supplemented. Coll. 1956 and 1957 by Astrid Linder, Royal Office of Natl. Antiquities; subm. by Mats P. Malmer, State Mus. of Natl. Antiquities, Stockholm.

\section{Svartviksudden, site 654}

\section{St-899. Svartviksudden HH30}

Cooking-pit. Charcoal $10 \mathrm{~cm}$ below surface.

$$
1750 \pm 80
$$

A.D. 200 
St-938. Svartviksudden 8

A.D. 1400

Hearth 8. Charcoal $7 \mathrm{~cm}$ below surface.

Vallviksudden, site 657

St-848. Vallviksudden 3

$1520 \pm 65$

A.D. 430

Trapping pit 3 . Charcoal $15 \mathrm{~cm}$ below surface.

St-849. Vallviksudden 4 A

$420 \pm 70$

A.D. 1530

Trapping pit 4. Charcoal from the upper part of the coal layer, $5 \mathrm{~cm}$ below surface.

St-850. Vallviksudden 4 B

$425 \pm 70$

A.D. 1525

Trapping pit 4. Charcoal from the lower part of the coal layer, $10 \mathrm{~cm}$ below surface.

\section{St-939. Vallviksudden 6}

Hearth 6. Charcoal $5 \mathrm{~cm}$ below surface.

St-940. Vallviksudden 7

Hearth 7. Charcoal $10 \mathrm{~cm}$ below surface.

St-941. Vallviksudden 9

Hearth 9. Charcoal $12 \mathrm{~cm}$ below surface.

St-942. Vallviksudden 10

Hearth 10. Charcoal $20 \mathrm{~cm}$ belof surface.

St-949. Vallviksudden 11

Hearth 11. Charcoal $10 \mathrm{~cm}$ below surface.

St-950. Vallviksudden 13

Hearth 13. Charcoal 15 to $20 \mathrm{~cm}$ below surface.

St-951. Vallviksudden 14

Hearth 14. Charcoal $20 \mathrm{~cm}$ below surface.

Lappvallen, site 662

\section{St-952. Lappvallen 2}

Hearth 2. Charcoal $20 \mathrm{~cm}$ below surface.

\section{St-953. Lappvallen 4}

Hearth 4. Charcoal $30 \mathrm{~cm}$ below surface.
A.D. 1550

$$
400 \pm 85
$$

$315 \pm 60$

A.D. 1635

$785 \pm 65$

A.D. 1165

A.D. 1220

$730 \pm 65$

$380 \pm 75$

A.D. 1570

$1365 \pm 95$

A.D. 585

$505 \pm 95$

A.D. 1445

$$
810 \pm 80
$$

A.D. 1140

A.D. 1300
$650 \pm 85$ 
St-954. Lappvallen 5

Hearth 5. Charcoal $15 \mathrm{~cm}$ below surface.

\section{St-955. Lappvallen 11}

Hearth 11. Charcoal $15 \mathrm{~cm}$ below surface.

St-1016. Lappvallen 25

Charcoal from pit of unknown function.

Bräntudden, site 673

St-866. Bräntudden 1 E
A.D. 1420

$530 \pm 80$

$670 \pm 90$

A.D. 1280

$1155 \pm 70$ A.D. 795

$1070 \pm 70$

A.D. 830

Cooking pit 1. Charcoal from the E part of pit, $40 \mathrm{~cm}$ below surface.

\section{St-867. Bräntudden 1 W}

$1260 \pm 70$

A.D. 690

Cooking pit 1. Charcoal from W part of pit, $25 \mathrm{~cm}$ below surface.

\section{St-868. Bräntudden 2}

Cooking pit 2. Charcoal $10 \mathrm{~cm}$ below surface.

\section{St-930. Bräntudden 2 N}

$1170 \pm 65$ A.D. 780

$1265 \pm 80$ A.D. 685

Hearth 2. Charcoal from $\mathrm{N}$ part of hearth, $15 \mathrm{~cm}$ below surface.

\section{St-937. Bräntudden 2 S}

$1120 \pm 65$ A.D. 830

Hearth 2. Charcoal from $\mathrm{S}$ part of hearth, $10 \mathrm{~cm}$ below surface.

\section{St-897. Bräntudden 3}

Hearth 3. Charcoal $5 \mathrm{~cm}$ below surface.

\section{St-898. Bräntudden 4}

Hearth 4. Charcoal $10 \mathrm{~cm}$ below surface.

$$
\begin{array}{r}
950 \pm 75 \\
\text { A.D. } 1000 \\
2580 \pm \mathbf{8 0} \\
630 \text { B.C. }
\end{array}
$$

\section{GEOCHEMICAL SAMPLES \\ A. Atmospheric Carbon Dioxide}

\section{Bredkälen series}

Atmospheric $\mathrm{CO}_{2}$ from Bredkälen $\left(63^{\circ} 54^{\prime} \mathrm{N}\right.$ Lat, $15^{\circ} 18^{\prime} \mathrm{E}$ Long), alt $400 \mathrm{~m}$, Jämtland, Sweden. Samples were collected at $2 \mathrm{~m}$ above ground level in an open grassland area by bubbling air through a $2 \mathrm{M} \mathrm{KOH}$ solution, which was changed twice monthly. The sampling period in question is indicated below by the four digits for year and month. A refers to the first half and B to the second half of the month. Sampling was begun in January 1959 and is still going on. Subm. by Svante Odén, Internatl. Meteorological Inst., Stockholm. Only selected samples have been analysed. 


\begin{tabular}{|c|c|c|c|}
\hline & & $\delta \mathrm{C}^{13}$ & $\Delta$ \\
\hline St-851. & 5901 A & -12 & $+178 \pm 15$ \\
\hline St-852. & 5907 A & -10 & $+338 \pm 10$ \\
\hline St-855. & 5912 A & -12 & $+262 \pm 7$ \\
\hline St-856. & $6003 \mathrm{~A}$ & -12 & $+214 \pm 13$ \\
\hline St-858. & $6005 \mathrm{~B}$ & -8 & $+251 \pm 15$ \\
\hline St-859. & $6008 \mathrm{~A}$ & -12 & $+278 \pm 10$ \\
\hline St-860. & $6012 \mathrm{~A}$ & -13 & $+270 \pm 10$ \\
\hline St-861. & $6102 \mathrm{~A}$ & -10 & $+218 \pm 10$ \\
\hline St-959. & $6102 \mathrm{~B}$ & -8 & $+232 \pm 10$ \\
\hline St-960. & $6103 \mathrm{~A}$ & -9 & $+252 \pm 13$ \\
\hline St-961. & $6103 \mathrm{~B}$ & -9 & $+251 \pm 20$ \\
\hline St-980. & $6104 \mathrm{~A}$ & -10 & $+248 \pm 18$ \\
\hline St-864. & $6107 A+B$ & -10 & $+249 \pm 15$ \\
\hline St-1013. & $6110 \mathrm{~A}$ & -9 & $+244 \pm 16$ \\
\hline St-1014. & $6201 \mathrm{~A}$ & -7 & $+230 \pm 15$ \\
\hline
\end{tabular}

Comment (G.Ö. and S.O.) : the $\Delta$ values show a magnitude and a seasonal variation similar to that reported by others. Maximum occurs around August, and minimum half a year later. This is in accordance with conditions of the stratosphere (source) and the earth surface (sink). For some periods the absorption was incomplete and the yield of $\mathrm{CO}_{2}$ rather low. This was connected with some isotopic fractionation (cf. $\delta \mathrm{C}^{13}$ figures) and leads to an increase of the uncertainty figures.

\section{B. Reaction Kinetics of Organic Substances in Soil}

\section{Hildesheim-Fredriksdal-Halmstad series}

Soil profiles from $\mathrm{N}$ Europe investigated to study the reaction kinetics of organic substances in soils. Subm. by Svante Odén.

\section{Hildesheim}

Soil profile between Harsum and Clausen $\left(52^{\circ} 18^{\prime} \mathrm{N}\right.$ Lat, $9^{\circ} 55^{\prime} \mathrm{E}$ Long), near Hildesheim, Germany. The soil belongs to the chernozem group, or black soils, and is degraded in this area. The soil profile has developed from calcareous loess and the depth of soil organic matter exceeds $150 \mathrm{~cm}$. The soil is used as farmland. Coll. June 1958 by Svante Odén. Prior to combustion, the samples were treated with dilute $\mathrm{HCl}$ to remove carbonate.

8 to $11 \mathrm{~cm}$ below soil surface. Organic carbon: $1.63 \%$ of dry weight. 
St-1020. Hildesheim 30-50 $\quad-26 \quad-226 \pm 8 \quad 2090 \pm 70$

30 to $50 \mathrm{~cm}$ below soil surface. Organic carbon: $1.06 \%$.

St-682. Hildesheim 68-71 $\quad-26 \quad-326 \pm 8 \quad 3170 \pm 65$

68 to $71 \mathrm{~cm}$ below soil surface. Organic carbon: $1.10 \%$.

\section{Fredriksdal}

Profile at Fredriksdal ( $56^{\circ} 03^{\prime} \mathrm{N}$ Lat, $12^{\circ} 42^{\prime} \mathrm{E}$ Long), near Hälsingborg, Skåne, Sweden. The soil consists of boulder clay from the NW moraine of Skåne. Organic matter is incorporated in the profile to a depth of $40 \mathrm{~cm}$, and from 40 to $60 \mathrm{~cm}$ below the surface is a gley horizon indicating high water table. Chemical data show the soil belongs to the Brown forest-soil group. For many centuries this area has been cultivated as farm land. Coll. in May 1957 by E. Lotse. Prior to combustion, samples were treated by HCl.

\section{$\begin{array}{lllll}\text { St-683. } & \text { Fredriksdal 0-20 } & -26 & -122 \pm 7 & 1045 \pm 60\end{array}$}

0 to $20 \mathrm{~cm}$ below soil surface. Organic carbon: $2.71 \%$ of dry weight.

St-1021. Fredriksdal 20-40 $\quad-27 \quad-120 \pm 7 \quad 1030 \pm 70$

20 to $40 \mathrm{~cm}$ below soil surface. Organic carbon: $1.59 \%$.

\section{Halmstad}

Samples taken S of the city of Halmstad ( $56^{\circ} 38^{\prime} \mathrm{N}$ Lat, $12^{\circ} 56^{\prime} \mathrm{E}$ Long), Halland, Sweden, in a large peneplain of outwash containing organic matter to a depth of $19 \mathrm{~cm}$. High water table has led to the formation of iron ore between 18 and $30 \mathrm{~cm}$ depth. The land has been cultivated as farm land for many centuries. Coll. Jan. 1960 and subm. by S. Odén. St-554A is an extraction of humic acids from the original sample, depth 0 to $19 \mathrm{~cm}$, and St-554B contains the insoluble fraction consisting of humine and humus coal. The extraction was made with $0.1 \mathrm{M} \mathrm{NaOH}$.

\section{St-554A. Halmstad A}

Humic acids. Organic carbon: $0.44 \%$ of dry weight, $15.8 \%$ of total carbon.

\section{St-554B. Halmstad B}

Humine and humus coal. Organic carbon: $2.36 \%$ of dry weight, $84.2 \%$ of total carbon.

\section{St-554. Halmstad Average}

Average, weighted by the relative amounts of carbon in samples A and B.

$$
\begin{array}{ccc}
\delta \mathrm{C}^{13} & \Delta & \text { Apparent Age } \\
-30 & -72 \pm 8 & 600 \pm 70
\end{array}
$$$$
-30 \quad-90 \pm 11 \quad 760 \pm 90
$$$$
-30 \quad-87 \pm 10 \quad 740 \pm 80
$$ 
General comment to Hildesheim-Fredriksdal-Halmstad series (S.O.) : $\mathrm{C}^{14}$ determinations of soil organic matter both from farm land and natural soils show a considerable apparent age, which is equivalent to a residence time of soil surface carbon of 200 to $2000 \mathrm{yr}$. On the other hand, the turnover time is much lower (10 to $50 \mathrm{yr}$ ) if independently measured by the inventory of carbon divided by the yearly flux. For a well mixed or exponential reservoir (cf. Eriksson, 1961) these times should be identical, and the observed difference for the soil organic matter indicates that the decomposition rate is not constant with time, but decreases, implying higher and higher resistance of the partially decomposed organic matter. From the knowledge of turnover time and residence time, one may compute coefficients for a decay function of the yearly amount of organic matter added to the soil (Odén, 1961). These coefficients seem to vary systematically both with latitude and the environment of the soil. The small age difference between St-554A and 554B (Halmstad) shows that humine and humus coal are not a "dead" carbon fraction in the soil, but are continuously decomposed and renewed. Besides these aspects of kinetics, the age distribution with depth of the Hildesheim profile gives interesting information concerning soil formation on loess. The low age at greater depth excludes the possibility of a continuous fossilization of soil organic matter as the loess deposition proceeds by eolian sedimentation.

\section{Haboskogen series}

Soil humus samples from a profile in a poor pine forest, ca. $40 \mathrm{yr}$ old, on strongly podzolized medium sand, at state forest Haboskogen, Section II $\left(57^{\circ}\right.$ $59^{\prime} \mathrm{N}$ Lat, $14^{\circ} 00^{\prime} \mathrm{E}$ Long), county of Skaraborg, Sweden. Alt $240 \mathrm{~m}$. Coll. 1934 and described by O. Tamm (1937) ; subm. by C. O. Tamm, Royal School of Forestry, Stockholm.

\section{St-815. Haboskogen cot 5599}

$$
\begin{array}{ccc}
\delta \mathrm{C}^{13} & \Delta & \text { Formal Age } \\
-22.5 & -40 \pm 8 & 330 \pm 65
\end{array}
$$

Dark brown cemented $\mathrm{B}_{1}$ horizon (hardpan) with a loss on ignition of $3.2 \%$ (oven-dry material). Approximate depth 20 to $25 \mathrm{~cm}$ below the top of $A_{1}$ horizon.

\section{St-816. Haboskogen cot 5600}

Lighter brown $\mathrm{B}_{2}$ horizon (no pan) below the $B_{1}$, depth of sampled layer ca. $8 \mathrm{~cm}$. Loss on ignition $2.1 \%$.

Comment (C.O.T.) : figures from this profile should be compared with the earlier dated soil profiles from Garpenberg (St-472, 473, and 474, Stockholm III) and Havtjärnsheden (St-575, 576, and 580, Stockholm IV). It is interesting to find in all three profiles formal ages of the B horizon humus ca. $400 \mathrm{yr}$. This can be taken as evidence of a dynamic equilibrium between supply and breakdown of organic matter in the B horizon of podzol profiles of the types studied. The early sampling (in 1934) of samples St-815 and 816 excludes any effect on the age determination of the recent contamination of the atmosphere with bomb produced $\mathrm{C}^{14}$. 


\section{Lappland B horizon series}

Samples from B horizon of iron podzols in Lappland, Sweden. There are two samples from each site, one from a well-stocked forest area $(F)$ and one from an open or poorly stocked area $(\mathrm{O})$. Coll. and subm. by Hilmar Holmen, Royal School of Forestry, Stockholm.

\begin{tabular}{|c|c|c|c|c|c|c|c|c|}
\hline St- & Site & N Lat, E Long & $\begin{array}{c}\text { Alti- } \\
\text { tude } \\
\text { above } \\
\text { sea } \\
\text { level, } \\
\text { m }\end{array}$ & $\begin{array}{c}\text { Or- } \\
\text { ganic } \\
\text { car- } \\
\text { bon } \\
\%\end{array}$ & $\begin{array}{c}\mathrm{cm} \\
\text { below } \\
\mathrm{A}_{1} \text { ho- } \\
\text { rizon }\end{array}$ & $\delta \mathrm{C}^{13}$ & $\Delta$ & $\begin{array}{c}\text { Formal } \\
\text { Age }\end{array}$ \\
\hline 900 & $610 \mathrm{~F}$ & 600900040 & 280 & 1.9 & $8-27$ & -25 & $-60 \pm 8$ & $500 \pm 65$ \\
\hline 901 & 6100 & $66^{\circ} 36^{\prime} 19^{\circ} 42^{\prime}$ & 320 & 1.8 & & -25 & & $460 \pm 65$ \\
\hline 902 & $967 \mathrm{~F}$ & $65^{\circ} 36^{\prime} 18^{\circ} 24^{\prime}$ & 35 & 3.7 & $10-46$ & -19 & & $620 \pm 65$ \\
\hline 903 & 9670 & $8^{\circ} 24^{\prime}$ & 520 & 4.3 & $5-31$ & -25 & $-145 \pm 7$ & $1260 \pm 60$ \\
\hline 904 & $972 \mathrm{~F}$ & & 435 & 3.0 & $4-30$ & -22 & & \\
\hline 905 & 9720 & & 435 & 1.4 & $6-26$ & -19 & & \\
\hline 906 & $991 \mathrm{~F}$ & & 410 & 1.1 & $6-40$ & -24 & & \\
\hline 907 & 9910 & & 410 & 1.3 & $8-40$ & -27 & & $910 \pm 65$ \\
\hline 908 & $992 \mathrm{~F}$ & & 400 & 2.6 & $8-20$ & -27 & & $630 \pm 65$ \\
\hline 909 & 9920 & & 400 & 2.0 & $3-18$ & -28 & & $490 \pm 60$ \\
\hline 910 & $1404 \mathrm{~F}$ & & 450 & 1.5 & $12-46$ & -18 & $-87 \pm 10$ & $730 \pm 80$ \\
\hline 911 & 14040 & $20^{\circ} 24^{\prime}$ & 455 & 2.4 & $7-38$ & -27 & $-90 \pm 8$ & $760 \pm 65$ \\
\hline 912 & $1405 \mathrm{~F}$ & $67^{\circ} 42^{\prime} 21^{\circ} 18^{\prime}$ & 320 & 1.8 & $8-32$ & -23 & $-59 \pm 11$ & $480 \pm 90$ \\
\hline 913 & 14050 & $67^{\circ} 42^{\prime} 21^{\circ} 18^{\prime}$ & 325 & 1.7 & $5-33$ & -20 & $-84 \pm 8$ & $705 \pm 65$ \\
\hline 914 & $1416 \mathrm{~F}$ & & 190 & 1.3 & $6-30$ & -22 & $-57 \pm 10$ & $470 \pm 80$ \\
\hline 915 & 14160 & $67^{\circ} 12^{\prime} 22^{\circ} 12^{\prime}$ & 210 & 1.3 & $7-40$ & -21 & $-92 \pm 7$ & $780 \pm 60$ \\
\hline
\end{tabular}

Comment (H.H.) : samples were collected as part of an investigation of the long-time effect on forest sites of a removal or reduction of the forest stand, as has often resulted from bad silvicultural practice (so-called soil degeneration). At the same time it was considered desirable to know more of the "residence time" of the organic matter in the mineral soil, since the total amount of this organic matter is often much greater than that of the "humus layer," even in iron podzols. The results are not quite conclusive, although it is clear that the average formal age of $\mathrm{N}$ Swedish $\mathrm{B}$ horizon humus is higher than that of podzol B horizon in S or middle Sweden (cf. St-474, 580, 815 and 816, Stockholm III and this list).

\section{Chemical Paleoclimate}

Sampling of ten raised peat bogs has been done in middle and S Sweden in order to estimate changes in the chemical climate of several thousand years ago. The bogs were selected both from a geologic point of view and with the object of obtaining localities far away from human activities. In each case, a $2 \mathrm{~m}$ profile was taken and sectioned at $4 \mathrm{~cm}$ intervals. Determinations have 
been made of dry matter, total nitrogen, calcium, magnesium, iron, alumina, and silica. Other determinations are under way. Dating will give a fairly good figure of growth rates of the bog, and consequently of the annual fixation of gaseous components from the air $\left(\mathrm{CO}_{2}, \mathrm{NH}_{3}\right.$, etc. $)$, or deposition rates of the elements listed above. All profiles coll. 1956 by Mrs. G. Linnman, Geol. Survey of Sweden; subm. by S. Odén. $\delta \mathrm{C}^{13}$.figures in parenthesis are presumed values, not measured.

\section{Laskerud series}

$$
\delta \mathrm{C}^{13} \quad \Delta \quad \mathrm{C}^{14} \text {-Age }
$$

Peat bog near Karlstad (59 $33^{\prime}$ N Lat, $13^{\circ} 47^{\prime}$ E Long) .

$\begin{array}{lrlrr}\text { St-840. } & 8-12 \text { cm depth } & -22 & -9 \pm 7 & 75 \pm 60 \\ \text { St-1022. } & 20-24 \quad \text { cm depth } & -27 & -76 \pm 8 & 635 \pm 70 \\ \text { St-1023. } & 32-36 \text { cm depth } & -27 & -96 \pm 8 & 810 \pm 70 \\ \text { St-991. } & 40-44 \text { cm depth } & -25 & -109 \pm 8 & 925 \pm 70 \\ \text { St-841. } & 76-80 \text { cm depth } & -23 & -128 \pm 9 & 1100 \pm 75 \\ \text { St-919. } & 100-104 \text { cm depth } & (-25) & -158 \pm 9 & 1380 \pm 75 \\ \text { St-842. } & 112-116 \text { cm depth } & -28 & -175 \pm 6 & 1540 \pm 50 \\ \text { St-920. } & 148-152 \text { cm depth } & (-25) & -207 \pm 9 & 1850 \pm 75 \\ \text { St-843. } & 192-196 \text { cm depth } & -27 & -234 \pm 9 & 2140 \pm 75\end{array}$

\section{Ryholm series}

Peat bog near Karlsborg ( $58^{\circ} 33^{\prime}$ N Lat, $14^{\circ} 14^{\prime}$ E Long)

$\begin{array}{lrlrr}\text { St-992. } & 12-16 \text { cm depth } & -23 & -45 \pm 8 & 370 \pm 65 \\ \text { St-871. } & 24-28 \text { cm depth } & -19 & -61 \pm 7 & 510 \pm 60 \\ \text { St-993. } & 60-64 \text { cm depth } & -24 & -110 \pm 8 & 935 \pm 70 \\ \text { St-872. } & 120-124 \text { cm depth } & -21 & -131 \pm 8 & 1135 \pm 65 \\ \text { St-873. } & 184-188 \text { cm depth } & -17 & -165 \pm 7 & 1440 \pm 60\end{array}$

\section{Mörhult series}

Peat bog near Jönköping (57 $31^{\circ} \mathrm{N}$ Lat, $14^{\circ} 15^{\prime} \mathrm{E}$ Long).

$\begin{array}{lcccr}\text { St-836. } & 4-8 \quad \text { cm depth } & -27 & -18 \pm 9 & 140 \pm 70 \\ \text { St-918. } & 32-36 \text { cm depth } & (-25) & -68 \pm 8 & 555 \pm 65 \\ \text { St-837. } & 60-64 \text { cm depth } & -27 & -92 \pm 7 & 780 \pm 60 \\ \text { St-838. } & 112-116 \text { cm depth } & -27 & -122 \pm 7 & 1050 \pm 60 \\ \text { St-839. } & 168-172 \text { cm depth } & -25 & -138 \pm 10 & 1185 \pm 80\end{array}$

\section{Yggeryd series}

Peat bog near Växjö ( $56^{\circ} 46^{\prime} \mathrm{N}$ Lat, $15^{\circ} 27^{\prime}$ E Long).

$\begin{array}{lrcrr}\text { St-921. } & 16-20 \text { cm depth } & -27 & +15 \pm 8 & \text { negative } \\ \text { St-994. } & 32-36 \text { cm depth } & -24 & -54 \pm 8 & 445 \pm 70 \\ \text { St-922. } & 68-72 \text { cm depth } & (-25) & -73 \pm 9 & 610 \pm 75 \\ \text { St-923. } & 164-168 \text { cm depth } & (-25) & -142 \pm 8 & 1220 \pm 70\end{array}$

Comment (S.O. and G.ö.) : the age increases very regularly with depth in these peat profiles. Growth rates at ca. $200 \mathrm{~cm}$ level range from 1.2 to $3.4 \mathrm{~mm}$ per year but are greatly decreased closer to surface $(0.4$ to $1.0 \mathrm{~mm}$ per year). At ca. $50 \mathrm{~cm}$ level both Laskerud and Yggeryd peat bogs show increased growth 
rates. The determination of growth rates over a limited interval by the $\mathrm{C}^{14}$. method is, however, fairly uncertain owing to the large probable error (e.g., for the interval St-841 to St-919, Laskerud the growth rate may well be 0.56 to $1.85 \mathrm{~mm}$ per year). At least one figure (St-921) is definitely influenced by bomb produced carbon, presumably brought down to this depth (16 to $20 \mathrm{~cm})$ by roots of surface vegetation. The $\delta \mathrm{C}^{13}$ figures do not show any systematic trend. The effect of cyclic enrichment is not clearly noted.

\section{Atlantic series}

Samples of seawater from various parts of the N Atlantic and Arctic Sea, collected during various cruises by S. Fonselius, Gothenburg Oceanographic Inst., A. Swanson and K. Wärme at the Internatl. Meteorological Inst., Stockholm. Some of the dates (St-322, 331, 332, 334, 335, and 336) have been dealt with by Fonselius and östlund (1959) and the results are here recalculated to the adopted NBS and PDB scales. Given in the description below: date of collection (yr, month, day), coordinates, depth, salinity and temperature.

\section{St-322. Gulf Stream}

$1957 / 03 / 30\left(62^{\circ} 36^{\prime} \mathrm{N}\right.$ Lat, $8^{\circ} 00^{\prime} \mathrm{W}$ Long $)$; $0 \mathrm{~m} ; 35.37 \%$; $+7.8^{\circ} \mathrm{C}$.

\section{St-331. Denmark Strait I}

$1957 / 04 / 02\left(67^{\circ} 48^{\prime} \mathrm{N}\right.$ Lat, $25^{\circ} 06^{\prime} \mathrm{W}$ Long) ; $0 \mathrm{~m} ; 32.72 \% \circ ;-1.6^{\circ} \mathrm{C}$.

\section{St-332. Denmark Strait II}

1957/04/10 (65ㅇ $30^{\prime} \mathrm{N}$ Lat, $26^{\circ} 36^{\prime} \mathrm{W}$ Long $)$; $0 \mathrm{~m} ; 33.17 \%$; $+6.0^{\circ} \mathrm{C}$.

\section{St-334. Denmark Strait III}

1957/04/17 (64 $48^{\prime} \mathrm{N} \mathrm{Lat,} 35^{\circ} 30^{\prime}$ W Long); $0 \mathrm{~m} ; 34.97 \%$; $+0.7^{\circ} \mathrm{C}$.

\section{St-335. Barents Sea I}

1957/07/03 (72 ${ }^{\circ} 54^{\prime} \mathrm{N}$ Lat, $41^{\circ} 48^{\prime}$ E Long); $337 \mathrm{~m} ; 34.98 \%$; $-0.7^{\circ} \mathrm{C}$.

\section{St-336. Barents Sea II}

1957/07/04 (73 $54^{\prime} \mathrm{N}$ Lat, $33^{\circ} 36^{\prime} \mathrm{E}$ Long); $0 \mathrm{~m} ; 35.08 \%$; $+4.9^{\circ} \mathrm{C}$.

St-458. Norwegian Sea 1

$1959 / 03 / 21$ ( $69^{\circ} 25^{\prime} \mathrm{N}$ Lat, $13^{\circ} 15^{\prime} \mathrm{E}$ Long) ; $0 \mathrm{~m}$; ca. $34 \%$; $+6.35^{\circ} \mathrm{C}$.

St-459. Norwegian Sea 6 1959/03/23 (64 $15^{\prime} \mathrm{N}$ Lat, 05 $16^{\prime} \mathrm{E}$ Long); $1000 \mathrm{~m} ; 34.92 \%$; $-0.93^{\circ} \mathrm{C}$.

\section{$\delta \mathrm{C}^{13}$ \\ $\Delta$}

$-0.7 \quad-35 \pm 7$

$$
-0.7 \quad-60 \pm 7
$$

$0.0 \quad-46 \pm 7$

$$
-0.5-36 \pm 9
$$$$
-0.5 \quad-38 \pm 6
$$

$-0.5 \quad-33 \pm 6$

$-2.6-34 \pm 11$

$-5.8 \quad-40 \pm 7$ 


$\begin{array}{lcc} & \delta \mathrm{C}^{13} & \Delta \\ \text { St-460. Norwegian Sea } 7 & -2.0 & -39 \pm 9 \\ 1959 / 03 / 23\left(64^{\circ} 15^{\prime} \mathrm{N} \text { Lat, } 05^{\circ} 16^{\prime} \text { E Long }\right) ; & & \\ ; 35.32 \% \text {; }+7.75^{\circ} \mathrm{C} . & & \\ \text { St-421. Bay of Biscay } & -3.0 & -22 \pm 7 \\ 1958 / 08\left(45^{\circ} \mathrm{N} \text { Lat, } 5^{\circ} \text { E Long) ; }\right. & & \\ \text {; salinity and temp. not recorded. }\end{array}$

\section{Kristineberg series}

Samples of seaweed and water, collected in Gullmarsfjorden at the Kristineberg Marine Research Station (58 $16^{\prime} \mathrm{N}$ Lat, $11^{\circ} 27^{\prime} \mathrm{E}$ Long), on W coast of Sweden. The seaweed samples were kindly submitted by Tore Levring, Marine Botanical Inst., Univ. of Gothenburg. Before combustion, the plants were leached with acid to remove carbonate. The sea-water samples were collected by M. Fokuda, Gothenburg Oceanographic Inst. The $\mathrm{CO}_{2}$ was extracted by the method described by Fonselius and östlund (1959). This series was an early attempt to trace the industrial and the atomic bomb effects in coastal sea water. Activity figures are age-corrected.

\section{St-365. Fucus 1905}

Fucus serratus, coll. 1905 at 0.5 to $5 \mathrm{~m}$ depth.

\section{St-363. Fucus 1950}

Fucus serratus, coll. 1950 at 0.5 to $5 \mathrm{~m}$ depth.

\section{St-355. Fucus 1958}

Fucus serratus, coll. in June 1958 at 0.5 to $5 \mathrm{~m}$ depth.

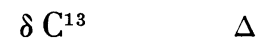

$$
-13 \quad-31 \pm 7
$$$$
-13 \quad-47 \pm 7
$$$$
-13 \quad-34 \pm 6
$$

St-369. Surface water 1958

Surface water coll. in June 1958.

St-364. Laminaria 1958

Laminaria Cloustonii, coll. in June 1958 at $20 \mathrm{~m}$ depth.

\section{St-370. Bottom water 1958}

Water coll. in June 1958 at ca. $20 \mathrm{~m}$ depth.

\section{St-428. Fucus 1959}

Fucus serratus, coll. in February 1959 at 0.5 to $5 \mathrm{~m}$ depth.

\section{ERRATUM}

St-739. Igelsta 9 in Stockholm IV, the comment should read: "date is older than expected. This ...".

\section{References}

G. Lundqvist (1962) has published a summary of geologic problems having been dealt with at this laboratory until the middle of 1962. In that paper our laboratory is erroneously called "The Stockholm Natural Radiocarbon Station". 
Date lists:

$\begin{array}{ll}\text { Miami I } & \text { Östlund, Bowman, and Rusnak, } 1962 \\ \text { Stockholm I } & \text { Östlund, 1957b } \\ \text { Stockholm II } & \text { Östlund, 1959 } \\ \text { Stockholm III } & \text { Östlund and Engstrand, 1960 } \\ \text { Stockholm IV } & \text { Engstrand and Östlund, 1962 } \\ \text { Uppsala I } & \text { Olsson, 1959 } \\ \text { Uppsala II } & \text { Olsson, 1960 } \\ \text { Yale II } & \text { Preston, Person, and Deevey, 1955 }\end{array}$

Ambrosiani, B., 1958, Darsgärdekomplexet: Fornvännen, v. 53, p. 161-176 (summary in English).

German).

Engstrand, L. G., and Östlund, H. G., Stockholm natural radiocarbon measurements IV: Radiocarbon, v. 4, p. 115-136.

Eriksson, E., 1961, Natural reservoirs and their characteristics: Geofisica Internac. (Mexico), v. 1 (2), p. $27-43$.

Fonselius, S., and Östlund, H. G., 1959, Natural radiocarbon measurements on surface water from the North Atlantic and the Arctic Sea: Tellus, v. 11, p. 77-83.

Fredsjö, Ä., 1953, Studier i Väst-Sveriges äldre stenålder: Arkeologiska museet i Göteborg, Skri., v. 1953, no. 1 , p. 32 and 105.

Hagberg, U. E., 1961, Skedemosse-en första presentation: Fornvännen, v. 56, p. 237-255 (summary in German). in German)

1962, Fiskekatsan idag och för 3500 år sedan: Tor, v. 8, p. 229-243 (summary

Lindquist, S. O., 1961, Some investigations of field-wall areas in Östergötland and Uppland: Geogr. Ann. Stockh., v. 1-2, p. 205-220.

Lundqvist, G., 1951, Beskrivning till jordartskarta över Kopparbergs län: Sveriges Geol. Undersökning ser. Ca, no. 21, fig. 104, p. 137.

1962, Geological radiocarbon datings from the Stockholm station: Sveriges Geol. Undersökning ser. C, no. 589, p. 20.

Magnusson, E., 1962, An interglacial or interstadial deposit at Gallejaure, Northern Sweden: Geol. Fören. Stockholm Förh., v. 84, p. 363-371.

Odén, S., 1961, Marken som humusreservoar: Lantbruksveckan, v. 1961, p. 74-81. 1963, A reservoir concept with selective properties: to be printed in Jour. Geophys. Res., v. 68.

Olsson, Ingrid, 1959, Uppsala natural radiocarbon measurements I: Am. Jour. Sci. Radioc. Supp., v. 1, p. 87-102.

1960, Uppsala natural radiocarbon measurements II: Am. Jour. Sci. Radioc. Supp., v. 2, p. 112-128.

Östlund, H. G., 1957a, Carbon dioxide proportional counting for natural radiocarbon measurements: Arkiv f. Kemi, v. 12, no. 6, p. 69-78.

493-497 1957b, Stockholm natural radiocarbon measurements I: Science, v. 126, p.

1959, Stockholm natural radiocarbon measurements II: Am. Jour. Sci. Radioc. Supp., v. 1, p. 35-44.

1962, A hydrogen gas counting system for natural tritium measurements: International Atomic Energy Agency, Vienna; Proc. Ser., "Tritium in the Physical and Biological Sciences," v. 1, p. 333-341.

Östlund, H. G., and Engstrand, L. G., 1960, Stockholm natural radiocarbon measurements III: Am. Jour. Sci. Radioc. Supp., v. 2, p. 186-196.

Östlund, H. G., Bowman, A. L., and Rusnak, G. A., 1962, Miami natural radiocarbon measurements I: Radiocarbon, v. 4, p. 51-56.

Preston, R. S., Person, Elaine, and Deevey, E. S., 1955, Yale natural radiocarbon measurements II: Science, v. 122, p. 954-960.

Tamm, O., 1937, Om de lågproduktiva sandmarkerna å Hökensås och i övre Lagadalen: Statens skogsförsöksanstalt, Meddelanden, v. 30, p. 1-66. (cf. fig. 3)

Thorarinsson, S., 1951, Laxárgljúfur and Laxárhraun. A tephrochronological study: Geogr. Ann. Stockh., v. 33, p. 1-89.

1954, The tephra-fall from Hekla on March 29th 1947: The Eruption of Hekla 1947-1948, II, 3; Reykjavík; H. F. Leiftur.

1960, The tephra-layers and tephrochronology: XXI Int. Geol. Congress, guide to excursion no. A2, p. 55-60.

Vries, Hessel de, and Barendsen, G. W., 1953, Radiocarbon dating by a proportional counter filled with carbon dioxide: Physica, v. 19, p. 987-1003. 